\title{
Long-term trend of surface ozone at a regional background station in eastern China 1991-2006: enhanced variability
}

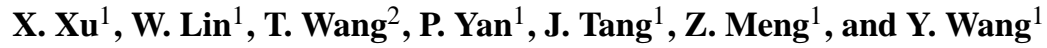 \\ ${ }^{1}$ Key Laboratory for Atmospheric Chemistry, Centre for Atmosphere Watch and Services, Chinese Academy of \\ Meteorological Sciences, China Meteorological Administration, Beijing, China \\ ${ }^{2}$ Department of Civil and Structural Engineering, The Hong Kong Polytechnic University, Hong Kong, China
}

Received: 17 October 2007 - Published in Atmos. Chem. Phys. Discuss.: 8 January 2008

Revised: 26 March 2008 - Accepted: 24 April 2008 - Published: 19 May 2008

\begin{abstract}
Information about the long-term trends of surface and tropospheric ozone is important for assessing the impact of ozone on human health, vegetation, and climate. Long-term measurements from East Asia, especially China's eastern provinces, are urgently needed to evaluate potential changes of tropospheric ozone over this economically rapid developing region. In this paper, surface ozone data from the Linan Regional Background Station in eastern China are analyzed and results about the long-term trends of surface ozone at the station are presented. Surface ozone data were collected at Linan during 6 periods between August 1991 and July 2006. The seasonality and the long-term changes of surface ozone at the site are discussed, with focus on changes in the diurnal variations, the extreme values, and the ozone distribution. Some long-term trends of surface ozone, e.g. decrease in the average concentration, increase in the daily amplitude of the relative diurnal variations, increase in the monthly highest $5 \%$ of the ozone concentration, decrease in the monthly lowest $5 \%$ of the ozone concentration, increase in the frequencies at the high and low ends of the ozone distribution have been uncovered by the analysis. All the trends indicate that the variability of surface ozone has been enhanced. Possible causes for the observed trends are discussed. The most likely cause is believed to be the increase of $\mathrm{NO}_{\mathrm{x}}$ concentration.
\end{abstract}

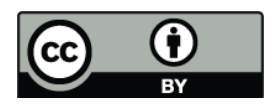

Correspondence to: $\mathrm{X} . \mathrm{Xu}$

(xuxb@cams.cma.gov.cn)

\section{Introduction}

Ozone is one of the key species in the atmosphere. It absorbs both solar UV and terrestrial IR radiation, therefore protects living organisms at the Earth's surface against the harmful solar UV radiation and influences the energy budget of the atmosphere (Staehelin et al., 2001). Tropospheric ozone is one of the greenhouse gases and governs oxidation processes in the Earth's atmosphere through formation of $\mathrm{OH}$ radical (Lelieveld et al., 2000). Since $\mathrm{OH}$ controls the lifetime of many atmospheric species, including $\mathrm{CH}_{4}, \mathrm{CO}$, VOCs, etc., changes in the abundance of ozone in the troposphere may have consequences in atmospheric chemistry and budget of other greenhouse gases. Moreover, high level of ozone in the boundary layer exerts negative influences on the human body, agricultural crops and natural vegetation (Chameides et al., 1999; Mauzerall et al., 2005). Due to the above importance, long-term trends and the distributions of ozone in the troposphere have been intensively studied (e.g. Carslaw, 2005; Fiore et al., 1998, 2002, 2005; Fusco and Logan, 2003; Gardner and Dorling, 2000; Jonson et al., 2006; Lelieveld and Dentener, 2000; Logan et al, 1999; Low and Kelly, 1992; Lu and Zhang, 2005; Menezes and Shively 2001; Naja and Akimoto, 2004; Oltmans et al., 1998, 2006; Qin et al., 2004; Simmonds et al., 2004; Tarasova et al., 2003; Vingarzan and Taylor, 2003).

While stratospheric ozone displayed a clear depleting trend between the late 1970s and the middle of the 1990s and some signs of recover after that (Newchurch et al., 2003; Staehelin et al., 2001; WMO, 2003), the situation regarding trends of tropospheric ozone is less clear. Although it is believed that global mean tropospheric ozone has increased from $25 \mathrm{DU}$ to $34 \mathrm{DU}$ since pre-industrial era, long-term

Published by Copernicus Publications on behalf of the European Geosciences Union. 
changes of tropospheric ozone are highly variable and depend on region and on the time period considered (Logan et al., 1999; Oltmans et al., 1998; WMO, 2003). The differences among regions appear to be especially large for the trends of surface ozone over the past three decades. A recent review (Vingarzan, 2004) shows that the surface ozone background trend is very inconsistent among monitoring stations. An increasing trend has been reported for 22 background stations, while a declining trend for 8 background stations. For many sites, no or mixed trends are reported of surface ozone (e.g. Logan et al, 1999; Low and Kelly, 1992; Tarasick et al., 2005; Vingarzan, 2004; Xu et al., 1996). This inconsistence requires more observational studies in various regions, particularly those with high emissions of ozone precursors.

The large regional variations in ozone trends can be attributed to the large natural variability in the troposphere, but also to fewer good long-term sets of ozone measurements (Staehelin et al., 2001). Ozone in the surface layer is highly variable due to its short lifetime there. Therefore a dense monitoring network with well-situated stations is needed to obtain reliable spatial-temporal distribution of surface ozone level. The background stations of the Global Atmosphere Watch (GAW) are suitable sites for monitoring the long-term change of surface ozone because they are usually situated at places less directly influenced by anthropogenic emissions. However, the background stations are quite unevenly distributed among different parts of the world (see http://www.empa.ch/gaw/gawsis/). Most background stations with long-term monitoring of surface ozone are located in North America and Europe, while only a few are located in some other important parts of world, e.g. East Asia. So far, studies of long-term trends of tropospheric ozone in East Asia are mainly based on ozonesonde data over Japan (Oltmans et al., 1998; Logan et al., 1999; Naja and Akimoto, 2004) and on MOZAIC aircraft data obtained in northern China (Ding et al., 2008). Long-term measurements from other parts of East Asia, especially China's eastern provinces, are urgently needed to evaluate potential changes of tropospheric ozone over this economically rapid developing region. Surface ozone has been observed at two mountain sites in East China since 2004 and data indicate that the ozone level at the sites may be strongly influenced by anthropogenic sources in the surrounding areas ( $\mathrm{Li}$ et al., 2007; Wang et al., 2006). In this paper, we present results about long-term trends of surface ozone at a background site in eastern China. We focus on the long-term changes in the variability of surface ozone at the site. Besides the trend of surface ozone level, we discuss the long-term changes of the diurnal variation of surface ozone, which have seldom been touched by earlier studies.

\section{Site and observations}

Data used in this study were collected at the Linan Regional Background Station $\left(30^{\circ} 18^{\prime} \mathrm{N}, 119^{\circ} 44^{\prime} \mathrm{E}, 139 \mathrm{~m}\right.$ a.s.l.), one of the regional GAW stations in China, established and operated by China Meteorological Administration (CMA). The station is located in the Yangtze Delta region, one of leading regions in economic growth in China. There are a few large cities in the E-NNW sector to Linan, with the nearest and largest being Hangzhou ( $\sim 50 \mathrm{~km}$ easterly) and Shanghai ( $\sim 210 \mathrm{~km}$ northeasterly), respectively. About $10 \mathrm{~km}$ to the south of the Linan station is the Linan Township with a population of approximately 50 thousands. More details about the site Linan are given in Wang et al. (2001).

To show the origins of air masses arriving at Linan, 5-day backward trajectories were computed every $6 \mathrm{~h}$ (at 00:00, 06:00, 12:00, and 18:00 UT) for the years 2005-2006 for $100 \mathrm{~m}$ above ground over Linan using the HYSPLITT 4 model (Draxler and Hess, 1997). Cluster analysis was applied to all trajectories of each season. Figure 1 displays the trajectory clusters of different seasons. In winter (DecemberFebruary), the site is predominately influenced by air masses from the north. In spring (March-May), nearly 50\% of the air masses arriving at Linan originate from the north, 10.5\% from the East China Sea, 29.2\% from Shanghai and Zhejiang Province, the rest $11.2 \%$ from Southern China. In summer (June-August), nearly $70 \%$ of the air masses originate from marine areas (South China Sea, Pacific Ocean, and Yellow Sea), indicating very strong effect of Asian summer monsoon. In fall (September-November), northerly streams dominate and marine air masses can still be transported to the site, but not as frequent as in summer.

Continuous long-term observation of surface ozone at Linan was started on 16 July 2005 . Before that time surface ozone was measured at the station for several periods. Table 1 summarizes some details of the periods with surface ozone measurements at Linan. During these periods the Model 49 or 49C ozone analyzer from the Thermo Environmental Instruments, Inc. (TEI) or Model 1003AH ozone analyzer from Dasibi Environmental Corp (Dashibi) have been used for the observation of surface ozone. Models 42S, 42C, or $42 \mathrm{CTL} \mathrm{NO}_{\mathrm{x}}$ analyzers (alternatively measuring $\mathrm{NO}$ and $\mathrm{NO}_{2}$ ) have been used for the $\mathrm{NO}_{\mathrm{x}}$ observation (see Table 1 for details). The TEI Model 49 and Dashibi Model 1003AH have a lower detection limit of $2 \mathrm{ppbv}$ and a precision of 2 ppbv, while the TEI Model 49C has a lower detection limit of $1 \mathrm{ppbv}$ and a precision of $1 \mathrm{ppbv}$. The $\mathrm{NO}_{\mathrm{x}}$ analyzers have a precision of $0.4 \mathrm{ppbv}$ and the lower detection limits for Model 42S, 42C, and 42CTL are $0.05 \mathrm{ppbv}, 0.4 \mathrm{ppbv}$, and 0.05 ppbv, respectively.

The comparability of the data from different periods is a prerequisite for the correctness of our results. During the different periods the instruments were calibrated at somewhat different intervals and using different methods. For the PEMWEST A and B campaigns, the instruments were calibrated 

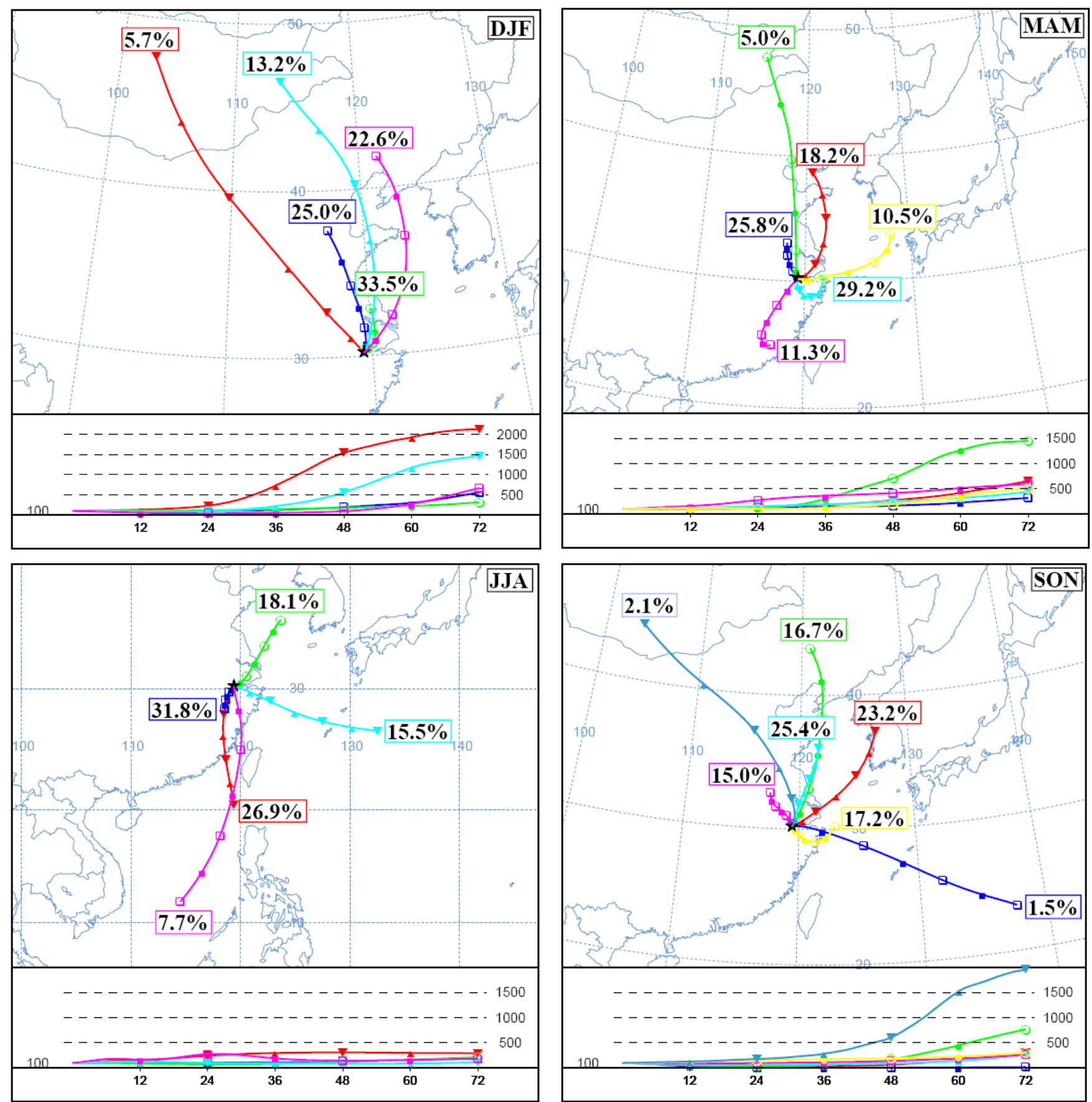

Fig. 1. Seasonal variation of air mass backward trajectories at Linan. Trajectory clusters for winter (left up), spring (right up), summer (left bottom), and fall (right bottom) are calculated based on the trajectories of 2005-2006. 72-h trajectories are shown with steps of $12 \mathrm{~h}$. The proportions of different clusters are given in the colored boxes.

on-site in the beginning, at about the half time, and at the end of the campaigns. During the period August 1994 to July 1995 multi-point calibration of the ozone analyzer was performed on-site in the beginning and about every 3 months using the gas phase titration method and the NO standard from US EPA. The $\mathrm{NO}_{\mathrm{x}}$ analyzer had technical problems before 2
April 1995 and after 31 May 1995. Therefore the $\mathrm{NO}_{\mathrm{x}}$ data from August 1994 to March 1995 and from May to July 1995 are not used in this paper. The $\mathrm{NO}_{\mathrm{x}}$ analyzer was calibrated on 2 April 1995. For the China-MAP and ACE-Asia campaigns (June 1999 to June 2001), the ozone analyzer and the $\mathrm{NO}_{\mathrm{x}}$ analyzer were checked on a daily basis using an internal 
Table 1. Periods with surface ozone data analyzed in this paper.

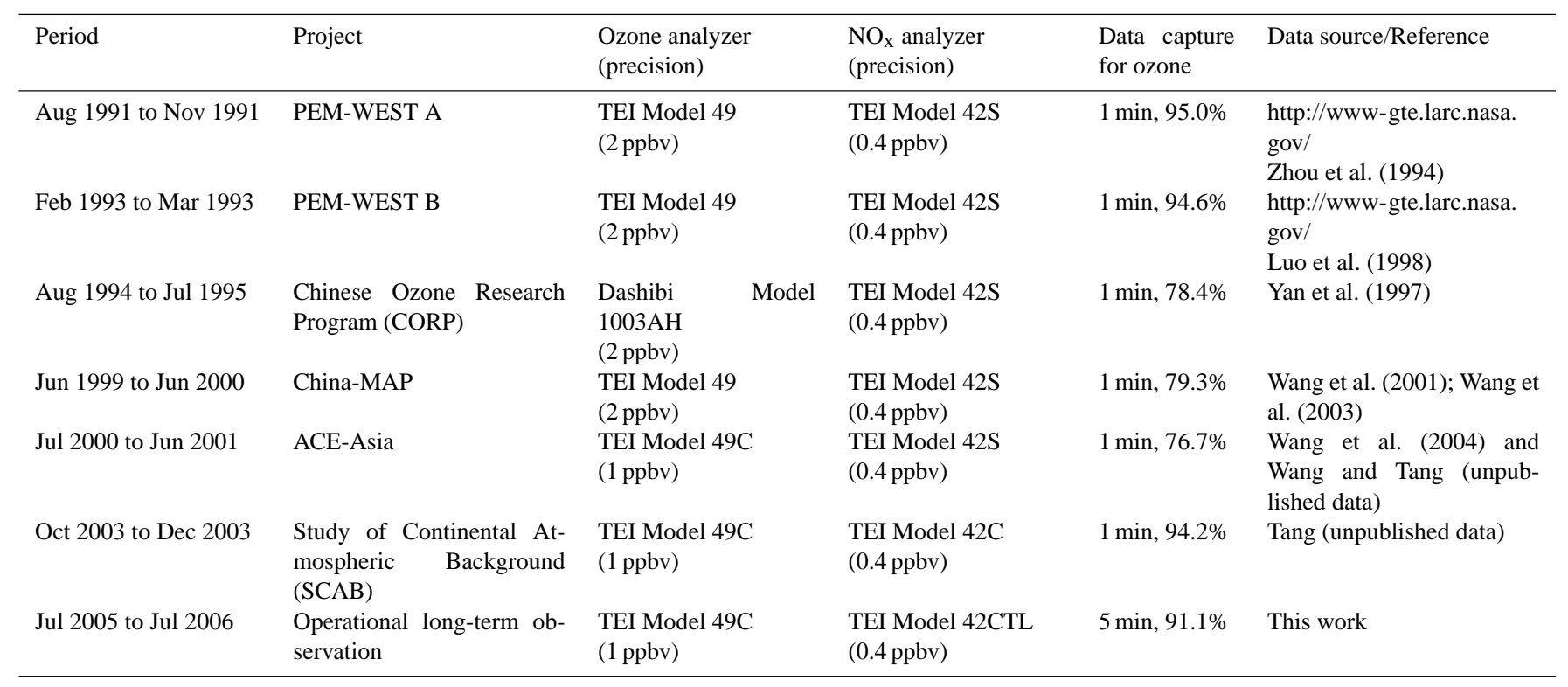

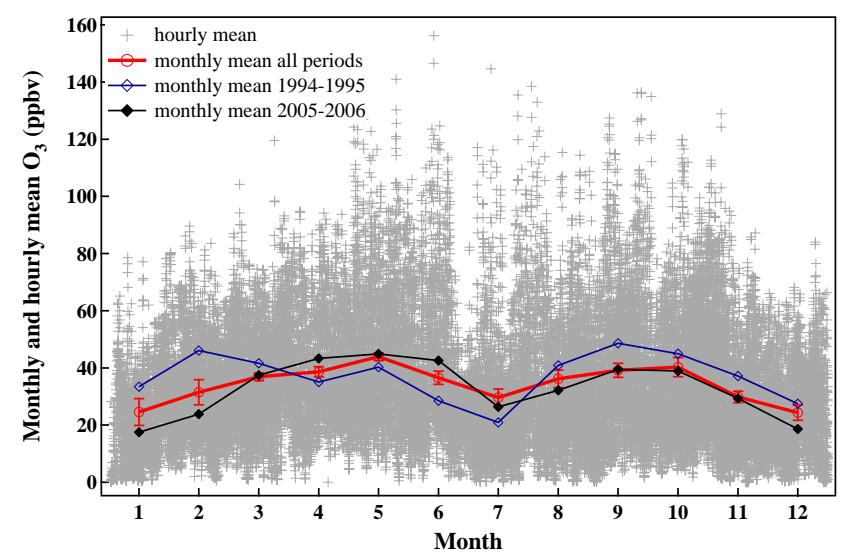

Fig. 2. Average seasonal cycle of surface ozone at Linan. The red circles indicate climatology monthly mean concentrations calculated from the monthly mean ozone concentrations of the same months of different years. The vertical bars represent one standard deviation of the climatology monthly mean concentrations. The blue and black lines represent the monthly mean ozone concentrations of the periods 1994-1995 and 2005-2006, respectively. The grey crosses represent hourly mean ozone concentrations from all periods listed in Table 1.

ozonator and a NIST traceable standard (Scott-Marrin Inc., California, USA), respectively. Multi-point calibrations were performed at roughly 3 -month intervals. More details about the instrument calibrations during this period are given in related publications (Cheung and Wang, 2001; Wang et al., 2002, 2004). For the SCAB campaign (October to December 2003), the ozone and $\mathrm{NO}_{\mathrm{x}}$ analyzers were zero-checked every week and calibrated on-site in the beginning using an ozone calibrator (TEI Model 49CPS) and a NO standard (National Centre for Standard Materials, Beijing, China), respectively. For the operational long-term observation since July 2005, zero checks of all analyzers have been made on a daily basis using a zero gas generator (TEI Model 111). The ozone and $\mathrm{NO}_{\mathrm{x}}$ analyzers have been span-checked daily using NO standard (Institute for Standard Materials, SEPA, Beijing, China) and the internal ozone source of a multi-gas calibrator (TEI Model 146C). Multi-point calibrations of the ozone analyzer were performed on 15 July 2005, 28 February 2006, and 20 November 2006 using an ozone calibrator (TEI Model 49CPS). Multi-point calibrations of the $\mathrm{NO}_{\mathrm{x}}$ analyzer were performed on 15 July 2005, 1 March 2006, and 19 November 2006 using the NO standard. Recently intercomparison between the ozone calibrator and the Standard Reference Photometer (SRP) \#41 from NIST shows a slope of $0.992 \pm 0.006$ (SRP vs. 49CPS).

Raw data of surface ozone were recorded every $5 \mathrm{~min}$ for the period July 2005 to July 2006 and every 1 min for all other periods. Calibration data and outliers related to malfunction of the data acquisition devices or ozone analyzers were removed from the high resolution raw data. In addition, failure of electricity occurred occasionally, leading to more gaps in the dataset. The estimated data capture (the number of total retained data points divided by that of total potential data points for each period) was in the range of $76.7 \%-95.0 \%$ (see Table 1). Hourly mean concentrations were calculated from the retained high resolution data and are used for further calculations in this paper. 


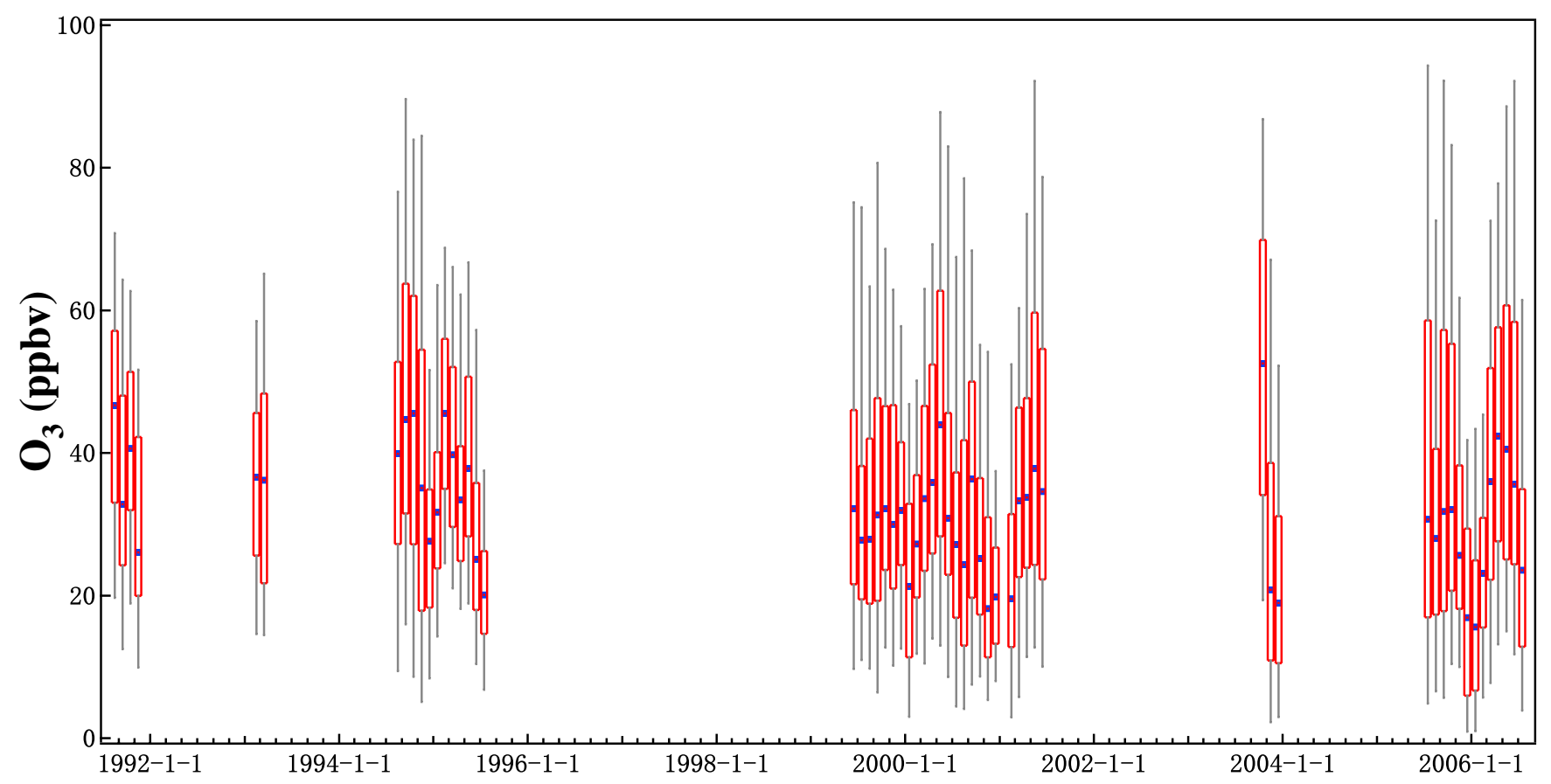

Fig. 3. Variations of monthly median (blue dash), 5-percentiles (whisker bottom), 25-percentile (box bottom), 75-percentile (box top), and 95-percentile (whisker top) of surface ozone concentrations observed at Linan during different periods.

\section{Results and discussion}

\subsection{Seasonal cycle}

Surface ozone at Linan varies strongly with season, as at many other rural sites. Data from four longer measurement periods (August 1994-July 1995, June 1999December 2000, February-June 2001, and July 2005-July 2006) demonstrates that the patterns, the annual amplitudes, and positions of maxima and minima of the seasonal cycles in surface ozone changed from period to period. To obtain average seasonal cycle the monthly mean ozone concentrations from different periods (including shorter periods) are averaged for each month of the year. Figure 2 shows the average seasonal variation. The seasonal cycle shows two peaks, with the primary being in May and the secondary in October. Between the two peaks there is a valley around July. This is attributed to Asian summer monsoon, which transports maritime air masses with low ozone concentration to and causes rainy weather in the region (Wang et al., 2001, see Fig. 1). The summer valley of surface ozone concentration has been observed also at some other Eastern Asian sites (e.g. Ghim and Chang, 2000; Lam et al., 2001; Li et al., 2007; Pochanart et al, 2002; Naja and Akimoto, 2004; Yamaji et al., 2006).

\subsection{Long-term variation of surface ozone}

Figure 3 shows the monthly statistical results (median, 5-, 25-, 75-, and 95-percentiles) of surface ozone measured at
Linan during seven periods between 1991 and 2006. As can be seen, surface ozone concentration varied in a very broad range within a month. Based on the statistics the monthly median of surface ozone concentration fluctuated in range of 15.6-52.6 ppbv, while the monthly average (not shown) varied from $17.5 \mathrm{ppbv}$ to $52.3 \mathrm{ppbv}$. A trend of $-(0.56 \pm 0.23) \mathrm{ppbv} \mathrm{yr}^{-1}$ for the monthly median and a trend of $-(0.37 \pm 0.23) \mathrm{ppbv} \mathrm{yr}^{-1}$ for the monthly average can be estimated by linear regression, suggesting that the concentration of surface ozone at Linan has been decreasing at a moderate rate. The trend for the monthly median is significant at 0.05 , while that for the monthly average is less significant.

The trends obtained as above should be viewed with caution as they might have been distorted by the large gaps and inhomogeneous distribution of the data points in the time series of surface ozone. Since some observation periods covered only 2-4 months and strong seasonality exits in the concentration of surface ozone at Linan (see Fig. 2), there may be artifact in the estimated trends. To avoid this potential problem, data from same time periods of different years are compared as an alternative method of deriving the ozone trend. Limited by the availability of data, such comparison cannot be done for all seasons but fall and late winter. Linear trends of $-(0.51 \pm 0.49) \mathrm{ppbv} \mathrm{yr}^{-1}\left(r^{2}=0.26\right)$ and $-(1.40 \pm 0.57) \mathrm{ppbv} \mathrm{yr}^{-1}\left(r^{2}=0.67\right)$ can be obtained by applying least-square fit to the average ozone concentrations for 20 August to 7 November of 1991, 1994, 1999, 2000, and 2005 and to those for February of 1993, 1995, 2000, 2001, and 2006, respectively. Although these trends are of low 
Table 2. Average, maximum, and minimum ozone concentrations in different seasons and years.

\begin{tabular}{|c|c|c|c|c|c|c|c|c|c|c|c|c|}
\hline \multirow{2}{*}{ year } & \multicolumn{3}{|c|}{ spring } & \multicolumn{3}{|c|}{ summer } & \multicolumn{3}{|c|}{ fall } & \multicolumn{3}{|c|}{ winter } \\
\hline & Avg & Max & Min & Avg & $\operatorname{Max}$ & Min & Avg & Max & Min & Avg & Max & Min \\
\hline 1991 & & & & & & & 37.8 & 100.4 & 6.8 & & & \\
\hline 1994 & & & & & & & 49.2 & 115.0 & 0.9 & & & \\
\hline 1994-1995 & & & & & & & & & & 36.0 & 89.6 & 0.8 \\
\hline 1995 & 40.0 & 119.5 & 0 & 21.7 & 110.9 & 3.1 & & & & & & \\
\hline 1999 & & & & 33.7 & 117.1 & 2.3 & 35.6 & 136.4 & 0.1 & & & \\
\hline 1999-2000 & & & & & & & & & & 28.4 & 70.6 & 0.5 \\
\hline 2000 & 40.2 & 124.2 & 0.5 & 32.8 & 144.6 & 0.2 & 33.0 & 136.2 & 0.3 & & & \\
\hline 2001 & 38.3 & 122.7 & 0.9 & & & & & & & & & \\
\hline 2005 & & & & & & & 38.4 & 134.9 & 0.3 & & & \\
\hline 2005-2006 & & & & & & & & & & 19.8 & 62.4 & 0 \\
\hline 2006 & 41.8 & 140.9 & 1.0 & 33.5 & 156.2 & 0.2 & & & & & & \\
\hline
\end{tabular}

or moderate significance, they indicate a decreasing trend of surface ozone, in agreement with the results from the analysis of the whole dataset. Therefore it is likely that the average concentration of surface ozone at Linan has been decreasing at a moderate rate since the early 1990s.

\subsection{Long-term trends of diurnal variations}

To see the long-term changes in the diurnal variation of surface ozone at Linan, seasonal average diurnal variations are calculated from the hourly mean data of the corresponding seasons. The periods 1 March-31 May, 12 June-18 July, 1 September-7 November, and 1 December-28 February, are selected to represent spring, summer, fall, and winter, respectively. It should be noted that limited by the availability of data, the periods 12 June-18 July and 1 September7 November cover only partially summer and fall days, respectively. The seasonal average diurnal variations relative to the corresponding average ozone concentrations (see Table 2) are calculated and shown in Fig. 4. As can be seen in this figure, the pattern of the average diurnal variations does not change substantially from period to period. Surface ozone reaches the lowest level between 06:00 and 08:00, increases rapidly to the maximum at about 15:00, and then decreases gradually to the minimum in the early morning of next day. Similar patterns of diurnal variation of surface ozone were observed at many other sites, where photochemistry contributes significantly to the fluctuation of surface ozone (e.g. Ghim and Chang, 2000; Saitanis, 2003; Dueñas, 2004; Zhang et al., 2007). The diurnal patterns of surface ozone at Linan, together with the large amplitudes, indicate that photochemical formation of ozone is one of the important factors in the Yangtze Delta region, at least in the warmer seasons.

It is noteworthy that there are apparent differences between the daily amplitudes of the relative diurnal variations for different years. The spring data in Fig. 4 show the lowest daily amplitude in 1995, a large increase of the daily am- plitude from 1995 to 2000, and a small increase from 2000 to 2001 and 2006. The summer diurnal cycles of surface ozone and their daily amplitudes in 1999, 2000, and 2006 look very similar and clearly different from those in 1995. The peak and valley positions of the diurnal variation of surface in 1995 appeared later and the daily amplitude was much smaller than those in the other years. The fall daily amplitude changed little from 1991 to 1994 , increased significantly to 1999 and 2000, and reached the highest in 2006. The winter data in Fig. 4 show a gradual and significant increase in the daily amplitude from 1994-1995 to 1999-2000 and to 2005-2006.

Figure 5 shows the long-term changes in the daily maximum and minimum of the relative diurnal variations of surface ozone at Linan, displaying in another way the increase tendency in the daily amplitude of surface ozone. As can be seen from Fig. 5, in all seasons the maximum of the relative diurnal variation has been increasing and the minimum decreasing. Linear trends of the maximum and minimum values are obtained by applying leastsquare fit to the data. The maximum value shows increase rates of $2.0 \% \mathrm{yr}^{-1}(\alpha<0.2), 2.7 \% \mathrm{yr}^{-1}(\alpha>0.2), 2.4 \% \mathrm{yr}^{-1}$ $(\alpha<0.05)$, and $2.0 \% \mathrm{yr}^{-1}(\alpha<0.05)$ for spring, summer, fall, and winter, respectively. The minimum value shows decrease rates of $0.8 \% \mathrm{yr}^{-1}(\alpha>0.2), 2.5 \% \mathrm{yr}^{-1}(\alpha<0.1), 1.8 \% \mathrm{yr}^{-1}$ $(\alpha<0.05)$, and $0.6 \% \mathrm{yr}^{-1}(\alpha<0.05)$ for spring, summer, fall, and winter, respectively.

In summary, some long-term changes in the diurnal variations of surface ozone at Linan have occurred since the early 1990s. These changes are (1) increase of the relative diurnal maximum, (2) decrease of the relative diurnal minimum, and (3) increase of the daily amplitude of surface ozone in all seasons. In other words, the variability of surface ozone at Linan has been enhanced over the last 15 years, with the daily maximum of surface ozone getting higher and the daily minimum getting lower. 


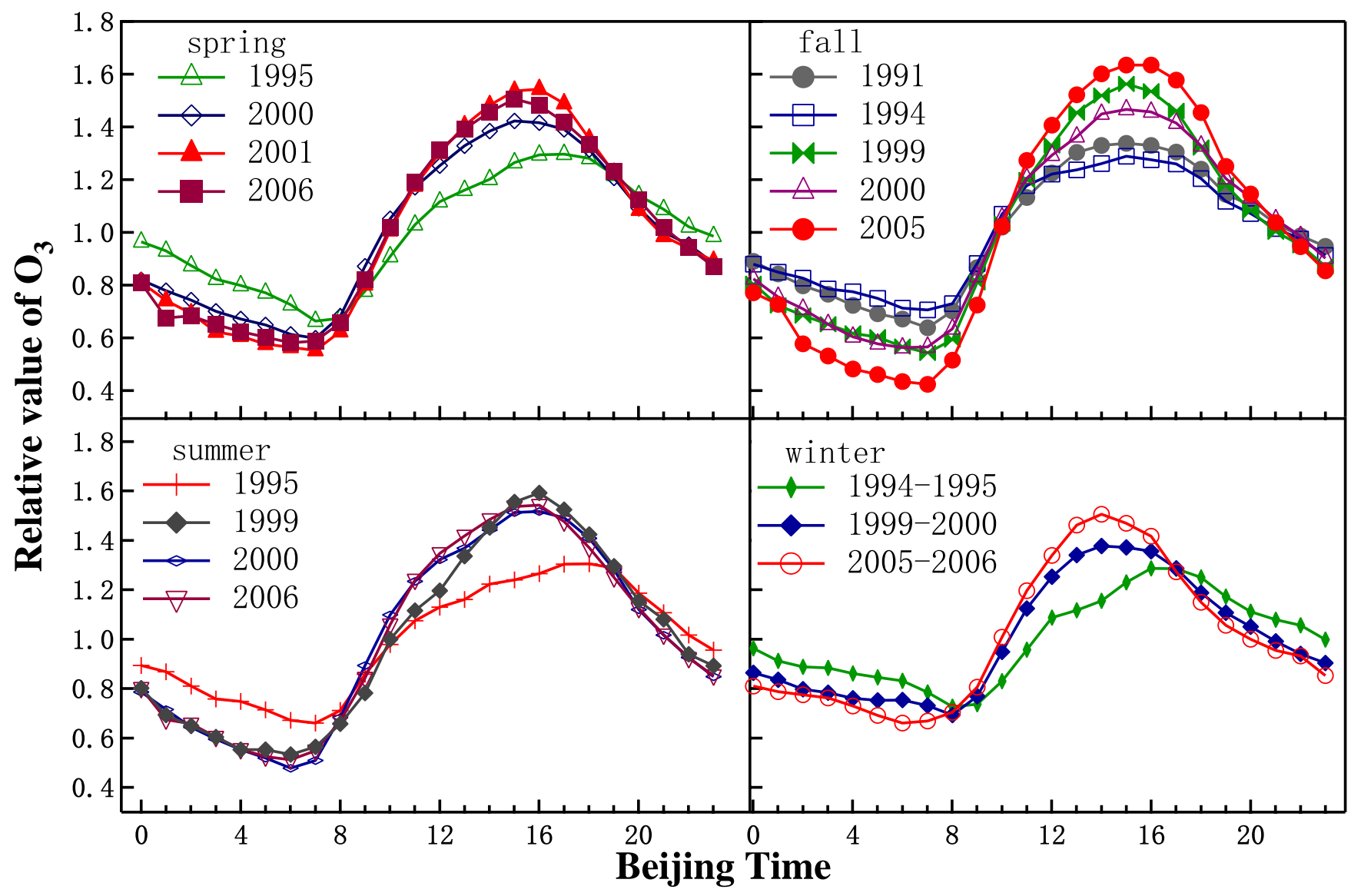

Fig. 4. Relative diurnal variations of surface ozone at Linan in spring (up-left), summer (bottom-left), fall (up-right), and winter (bottomright) of different years. Each curve in the figure represents a seasonal average diurnal variation relative to the average ozone concentration of the corresponding season and year (see Table 2), so that the values are dimensionless.

\subsection{Long-term trend of extreme values}

In the previous section the long-term changes in the variability of surface ozone at Linan are demonstrated using the data of relative diurnal variation. In this section, the longterm changes are illustrated using the observed extreme values of surface ozone at the station. Values greater than the 95-percentile of the hourly mean ozone concentrations in a month are averaged to obtain the average of the monthly highest 5\%, while values lower than the 5-percentile are averaged to obtain the average of the monthly lowest $5 \%$. Nearly $96 \%$ of the values greater than the 95-percentiles occurred in daytime (Beijing Time 08:00-20:00) and 86\% of the values lower than the 5-percentiles occurred during the night (Beijing Time 20:00-08:00). Figure 6 shows the averages of the monthly highest $5 \%$ and lowest $5 \%$ of the hourly mean ozone concentrations at Linan. As can be seen in the figure, the data points are much scattering, especially those of the monthly highest $5 \%$, nevertheless, we performed leastsquare fitting to the data to obtain the trends of both types of extreme values. The slopes of the two regression lines (gray dashed line and red solid line in Fig. 6) indicate that the highest and lowest values of surface ozone at Linan have different trends. The average of the monthly highest $5 \%$ has increased at a rate of $0.68 \mathrm{ppbv} \mathrm{yr}^{-1}$, while the average of the monthly lowest $5 \%$ has decreased at a rate of $0.53 \mathrm{ppbv} \mathrm{yr}^{-1}$. It should be noted that the trend of the highest $5 \%$ values is less significant $(\alpha>0.05)$ due to strong variations in the values. Inspecting the colored points of the highest $5 \%$ values for different seasons, one can recognize that the larger scattering can be attributed partly to the seasonal differences. The winter values are far apart from the group. While data from other seasons show an increasing trend, the winter data show a decreasing trend of $1.4 \mathrm{ppbv} \mathrm{yr}^{-1}(\alpha<0.05)$. The most rapid increase has occurred in the monthly highest $5 \%$ in summer, with a rate of $1.8 \mathrm{ppbv} \mathrm{yr}^{-1}(\alpha<0.05)$.

In consequence of the above long-term changes the distribution of the concentration of surface ozone at Linan has changed significantly since about a decade. Figure 7 shows the distributions of the hourly mean concentrations of surface ozone at Linan, for the 1994-1995, 1999-2001, and 2005-2006 periods, respectively. Effective hourly mean data 


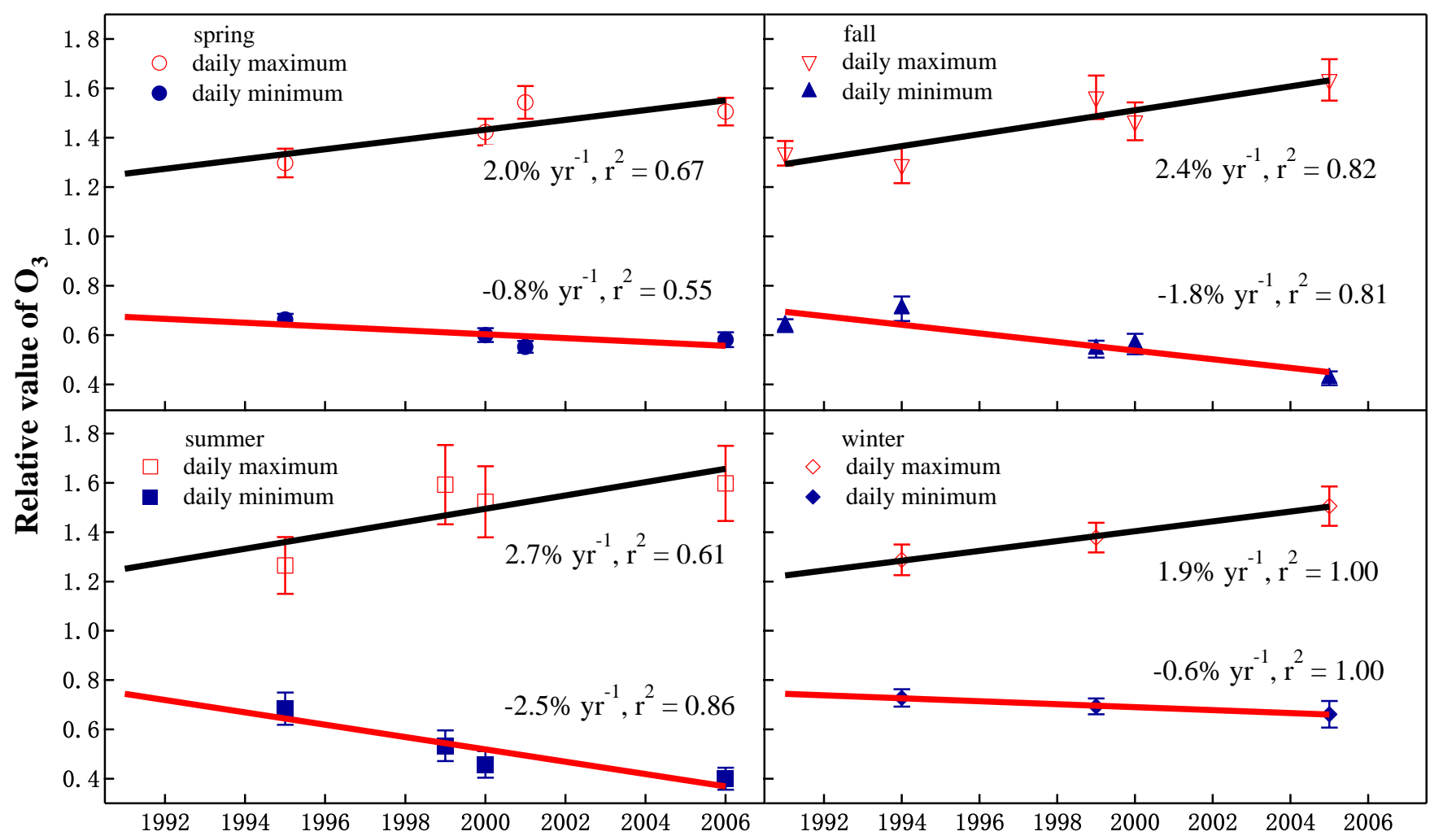

Fig. 5. Long-term changes in the daily maximum and minimum of the relative diurnal variations of surface ozone at Linan in different seasons. The daily maximum and minimum values represent the peaks and valleys of the seasonal average diurnal variations of surface ozone in Fig. 4.

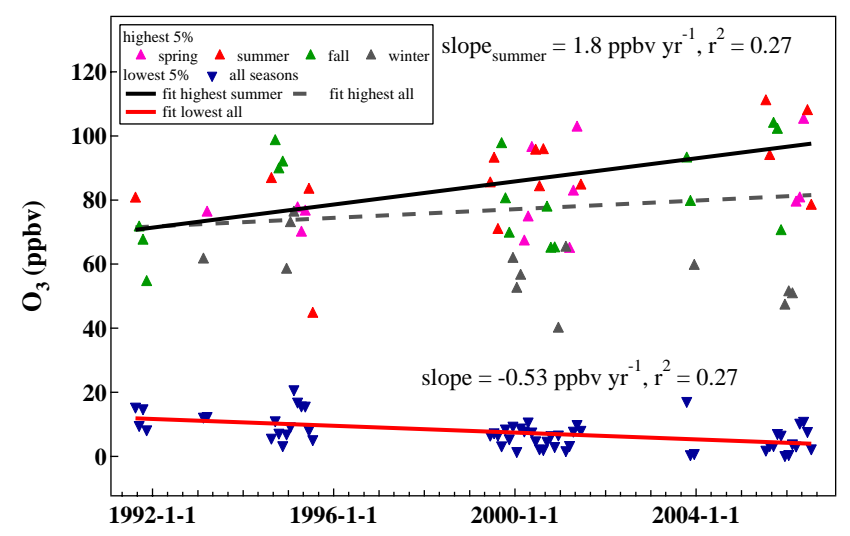

Fig. 6. Long-term changes in averages of the monthly highest $5 \%$ and lowest $5 \%$ of surface ozone at Linan.

points from periods 1994-1995, 1999-2001, and 2005-2006 are 6325,14677 , and 8779 , respectively. As can be seen in Fig. 7 and the blowup in it, the leftmost part of the distribution curve has shifted towards left and the rightmost towards right, suggesting that both extreme low and extreme high concentrations have become more frequent and the ozone concentration has become more variable. It is also notewor- thy that the shift towards the low end of the distribution was stronger than the shift towards the high end, i.e. more and more data points are distributed in the lower ozone concentration range and less and less in the higher ozone concentration range. In consequence of these shifts, the peak of the distribution curve of surface ozone has shifted towards lower value despite an increase in variance of ozone concentration.

\subsection{Possible causes for the observed long-term trends}

Surface ozone is closely related to many processes, such as photochemistry, dry deposition, transport, etc. It is well known that $\mathrm{NO}_{\mathrm{x}}$ are key species for the variation of tropospheric ozone. In the presence of sufficient sunlight $\mathrm{NO}_{\mathrm{x}}$ catalyze the photochemical oxidation of VOCs and other species to form ozone. During nighttime and in the cold seasons with no or less intensive sunlight $\mathrm{NO}_{\mathrm{x}}$ remove ozone through titration reaction, in which $\mathrm{NO}$ reacts with ozone to form $\mathrm{NO}_{2}$. Therefore changes in the $\mathrm{NO}_{\mathrm{x}}$ emission may have different effects on the variability of surface ozone, depending on time and location. Theoretically, if other conditions remain stable, a larger or smaller $\mathrm{NO}_{\mathrm{x}}$ emission can lead to enhancement or reduction in the variability of surface ozone. Indeed a few studies (e.g. Lefohn et al., 1998; Lin et al., 2000; TOR-2, 2003; Solberg et al., 2004; Ordóñez et 


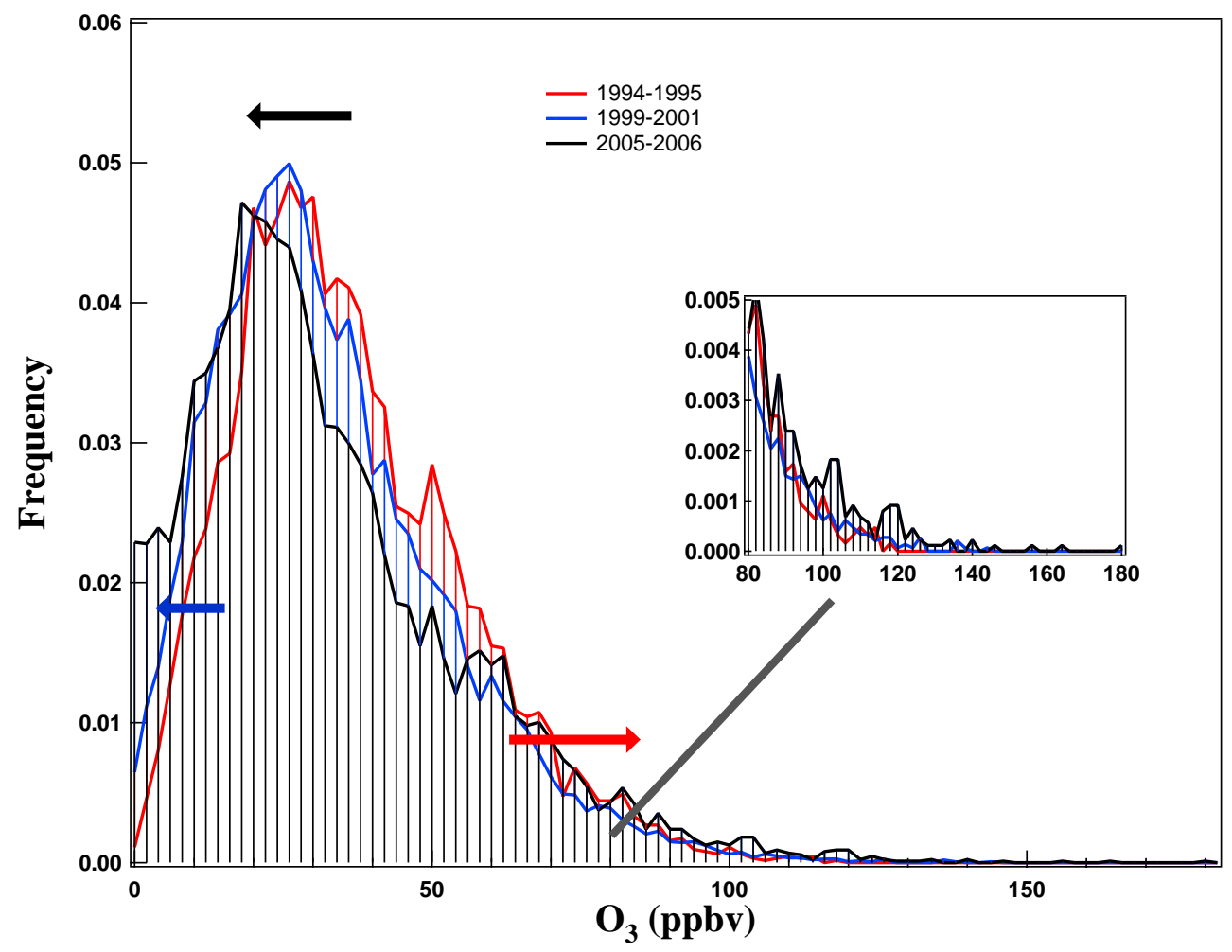

Fig. 7. Distributions of the hourly mean concentrations of surface ozone at Linan, for the periods 1994-1995, 1999-2001, and 2005-2006. The frequencies are values relative to the total numbers of data points from different periods (see text for details). The blow-up shows the details of the right tails of the distributions. The blue and red arrows indicate the respective shift directions of the leftmost and rightmost parts of the distribution curves, and the black arrow indicates the shift direction of the peak of the distribution curves.

al., 2005; Chou et al., 2006; Jonson et al., 2006) show either a decrease in high ozone concentrations or an increase in low ozone concentrations or both, consistent with the local decline in $\mathrm{NO}_{\mathrm{x}}$ emission. These changes reduce the variability of surface ozone. To our best knowledge there has been virtually no previous study showing enhancement in the variability of surface ozone at background site as a result of increasing $\mathrm{NO}_{\mathrm{x}}$ level. We believe that the enhanced variability of surface ozone shown in Sects. 3.3 and 3.4 is such an example.

The Yangtze Delta region, in which Linan is located, is one of most densely populated and industrialized regions in China. Booming economy in and outside the region has been causing significant increase in the emissions of some key pollutants (Streets et al., 2003). As a result, the atmospheric concentrations of the pollutants have been increasing. Richter et al. (2005) and Zhang et al. (2007) report a large increase of the tropospheric column of $\mathrm{NO}_{2}$ over East Central China. In situ measurements show that $\mathrm{NO}_{\mathrm{x}}$ concentration at Linan has been increasing since 1992, as shown in Fig. 8. In addition, there have been some changes in the frequency distribution of the $\mathrm{NO}_{\mathrm{x}}$ concentration. The frequency distributions of the hourly mean $\mathrm{NO}_{\mathrm{x}}$ concentration from the periods 1999-2001 and 2005-2006 are displayed in

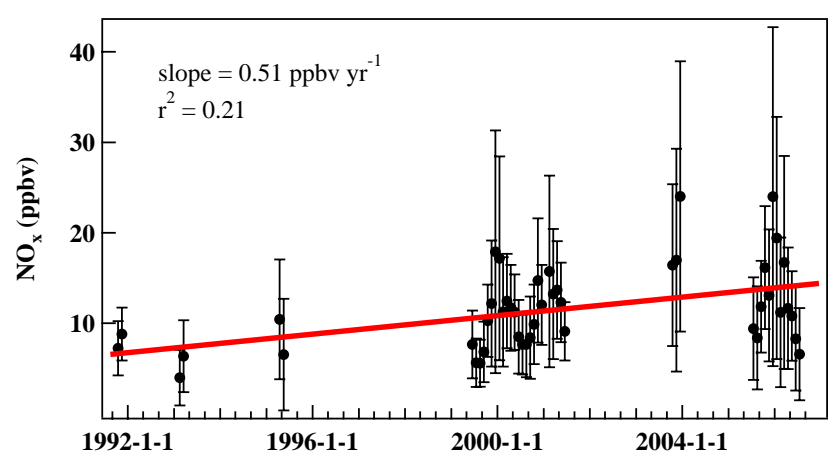

Fig. 8. Monthly mean $\mathrm{NO}_{\mathrm{x}}$ concentration at Linan. The vertical bars represent the standard deviation of the monthly mean concentration.

Fig. 9. They look similar but differ in details. The frequencies of lower and higher $\mathrm{NO}_{\mathrm{x}}$ concentrations during 20052006 were higher than those during 1991-2001, while frequencies of the concentrations around median during 20052006 were lower than those during 1991-2001. The overall effect of above changes in the frequency distribution is an increase of the average $\mathrm{NO}_{\mathrm{x}}$ concentration, from $11.1 \mathrm{ppbv}$ in 1999-2001 to $13.4 \mathrm{ppbv}$ in 2005-2006. The increase rate of 


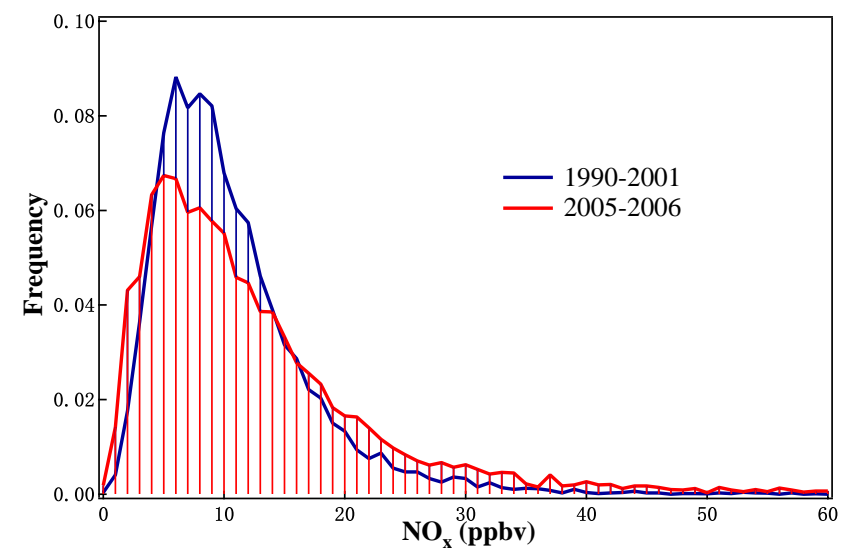

Fig. 9. Distributions of the hourly mean concentrations of $\mathrm{NO}_{\mathrm{x}}$ at Linan for the periods 1999-2001 and 2005-2006.

$\mathrm{NO}_{\mathrm{x}}$ concentration at Linan is estimated to be $0.51 \mathrm{ppbv} \mathrm{yr}^{-1}$ (Fig. 8). Interestingly, this $\mathrm{NO}_{\mathrm{x}}$ trend is close to the decrease rate of the monthly lowest $5 \%$ and the increase rate of the monthly highest $5 \%$ of ozone concentration (see Fig. 6). From August 1999 to July 2006 the $\mathrm{NO}_{\mathrm{x}}$ concentration at Linan increased at a rate of about $3.2 \% \mathrm{yr}^{-1}$. This growth rate is large enough to have significant impacts on surface ozone. Luo et al. (2000) pointed out that ozone formation in rural areas in the Yangtze Delta region is $\mathrm{NO}_{\mathrm{x}}$-limited. Wang et al. (2001) reported a positive correlation between ozone and $\mathrm{NO}_{\mathrm{x}}$ during afternoon hours at Lin'an in summer months, providing observational evidence for the $\mathrm{NO}_{\mathrm{x}}{ }^{-}$ limited chemistry. Therefore the increasing trend of $\mathrm{NO}_{\mathrm{x}}$ may have caused more daytime production of ozone, especially during warmer months, and more titration of ozone during nighttime and cold months. These effects are consistent with the phenomena discussed in Sects. 3.3 and 3.4. To further support this idea, the monthly lowest $5 \%$ of ozone in colder months (November to April) and the monthly highest $5 \%$ of ozone in warmer months (May to October) are compared with the corresponding monthly mean $\mathrm{NO}_{\mathrm{x}}$ concentration. Figure 10 shows the results of these comparisons. The monthly lowest $5 \%$ of ozone in colder months is negatively correlated to the monthly mean $\mathrm{NO}_{\mathrm{x}}$ concentration $(\alpha<0.01)$, while the monthly highest $5 \%$ of ozone in warmer months is positively correlated to the monthly mean $\mathrm{NO}_{\mathrm{x}}$ concentration $(\alpha<0.05)$. Hence it is likely that the observed long-term trends in the variability of surface ozone at Linan are mainly caused by the increase of $\mathrm{NO}_{\mathrm{x}}$ concentration in the Yangtze Delta region.

It should be noted that some other factors may also have contributed to the changes in the variability of surface ozone. These factors include increasing emission of NMHCs, stratospheric ozone depletion, etc. Indeed measurements show that the total concentration of NMHCs at Linan tripled in the decade from 1994 to 2004 (Xu et al., 1996; Wang et al., 2006). The increase of NMHCs concentration may have con-
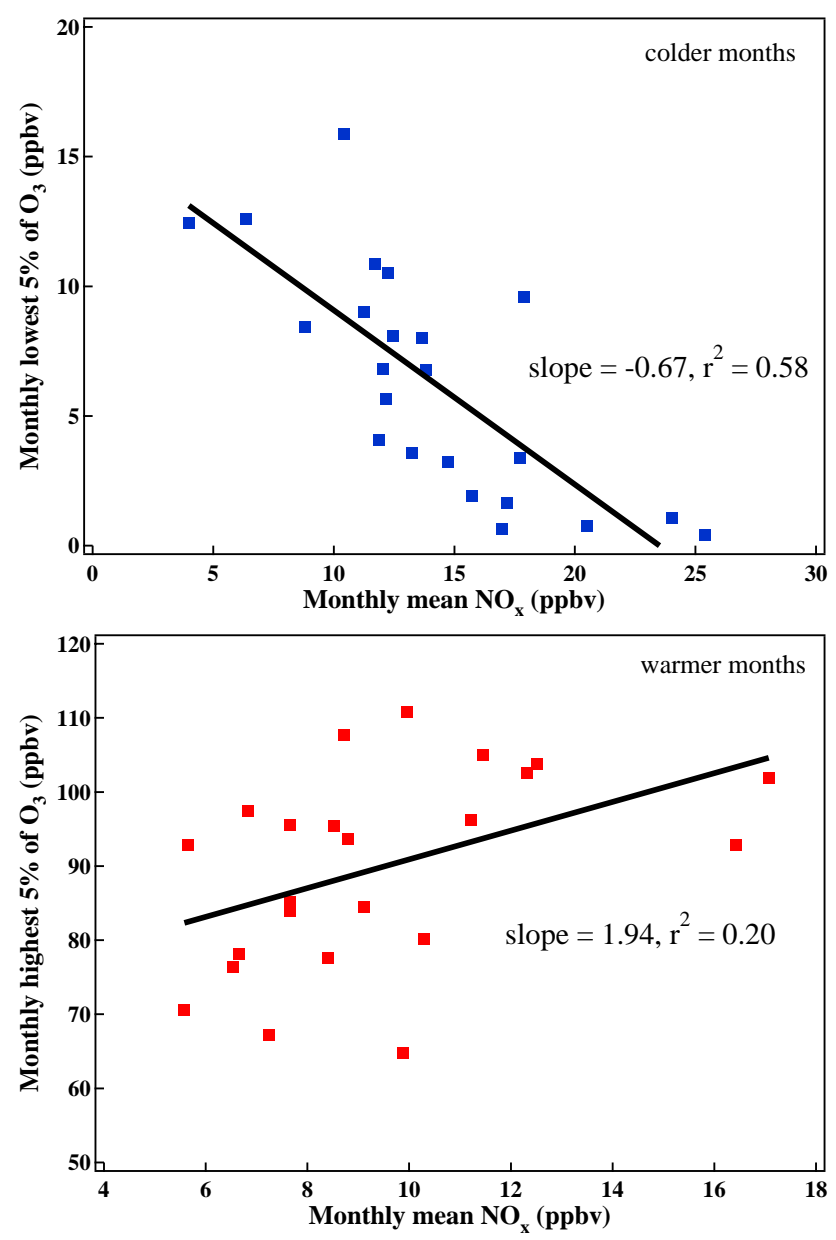

Fig. 10. Correlations between the monthly lowest $5 \%$ of $\mathrm{O}_{3}$ and the monthly mean $\mathrm{NO}_{\mathrm{x}}$ concentration in colder months (May to October) and between the monthly highest $5 \%$ of $\mathrm{O}_{3}$ and the monthly mean $\mathrm{NO}_{\mathrm{x}}$ concentration in warmer months (November to April) at Linan.

tributed to more photochemical production of ozone. However, it is unlikely that this increase have caused a significant decreasing trend of the low end of the ozone distribution. The temperature at Linan has been quite stable (with change

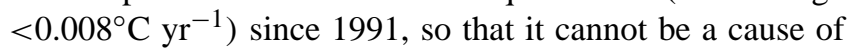
the trend in the variability of surface ozone. Secular changes (if any) in transport and dry deposition of ozone would have influenced the ozone concentration at Linan. However, it is unclear whether or not such changes have occurred. Moreover, it seems to be unlikely that the changes in transport and dry deposition can explain all the trends shown in Sects. 3.3 and 3.4.

\section{Conclusions}

In this paper we present some long-term trends of the features of surface ozone at Linan including: a decrease in the 
average concentration, an increase in the daily amplitude of the relative diurnal variation, an increase in the monthly highest $5 \%$ and a decrease in the monthly lowest $5 \%$ of the ozone concentration, and an increase in the frequencies at the high and low ends of the ozone distribution. All the trends indicate that the variability of surface ozone has been enhanced. We believe that the enhanced variability of surface ozone is mainly caused by an increase of $\mathrm{NO}_{\mathrm{x}}$ concentration or emission in the Yangtze Delta region, in which Linan is located. Because this study is based on the intermittent measurements made during several periods in the last 15 years, modeling studies are needed to better understand the observed trends and their causes. The increase in the extreme high concentration may have negative impact on human health and vegetation and can also change the oxidizing capacity on which atmospheric chemistry highly depends. Therefore monitoring of surface ozone at the site should be continued and control measures should be taken to avoid further exacerbation of ozone pollution.

Acknowledgements. We thank the staff of the Linan station for carrying out the measurements. This work is supported by the CMA project (CCSF2005-3-DH02) and the "National Basic Research Program of China" (No. 2005CB4222002 and 2005CB4222003). $\mathrm{X}$. Xu thanks the grant from the Ministry of Personnel of the People's Republic of China.

Edited by: F. J. Dentener

\section{References}

Carslaw, D. C.: On the changing seasonal cycles and trends of ozone at Mace Head, Ireland, Atmos. Chem. Phys., 5, 34413450, 2005, http://www.atmos-chem-phys.net/5/3441/2005/.

Chameides, W. L., Li, X., Tang, X., Zhou, X., Luo, C., Kiang, C. S., John, J. St., Saylor, R. D., Liu, S. C., Lam, K. S., Wang, T., and Giorgi, F.: Is ozone pollution affecting crop yields in China, Geophys. Res. Lett., 26, 867-870, 1999.

Cheung, V. T. F. and Wang, T.: Observational study of ozone pollution at a rural site in the Yangtze Delta of China, Atmos. Environ., 35, 4947-4958, 2001.

Chou, C. C.-K., Liu, S. C., Lina, C.-Y., Shiu, C.-J., and Chang, K.H.: The trend of surface ozone in Taipei, Taiwan, and its causes: Implications for ozone control strategies, Atmos. Environ., 40, 3898-3908, 2006.

Ding, A. J., Wang, T., Thouret, V., Cammas, J.-P., and Nédélec, P.: Tropospheric ozone climatology over Beijing: analysis of aircraft data from the MOZAIC program, Atmos. Chem. Phys., 8, 1-13, 2008, http://www.atmos-chem-phys.net/8/1/2008/.

Draxler, R. R. and Hess, G. D.: Description of the HYSPLIT_4, modeling system, NOAA Tech. Memo. ERL ARL-224, 24 pp., NOAA, Silver Spring, Md., 1997.

Dueñas, C., Fernández, M. C., Cañete, S., Carretero, J., and Liger, E.: Analyses of ozone in urban and rural sites in Málaga (Spain), Chemosphere, 56, 631-639, 2004.
Fiore, A. M., Jacob, D. J., Logan, J. A., and Yin, J. H.: Long-term trends in ground level ozone over the contiguous United States, 1980-1995, J. Geophys. Res., 103(D1), 1471-1480, 1998.

Fiore, A. M., Jacob, D. J., Bey, I., Yantosca, R. M., Field, B. D., and Fusco A. C.: Background ozone over the United States in summer: origin, trend, and contribution to pollution episodes, J. Geophys. Res., 107(D15), 4275, doi:10.1029/2001JD000982, 2002.

Fiore, A. M., Horowitz, L. W., Purves, D. W., Levy II, H., Evans, M. J., Wang, Y., Li, Q., and Yantosca, R. M.: Evaluating the contribution of changes in isoprene emissions to surface ozone trends over the eastern United States, J. Geophys. Res., 110, D12303, doi:10.1029/2004JD005485, 2005.

Fusco, A. C. and Logan, J. A.: Analysis of 1970-1995 trends in tropospheric ozone at Northern Hemisphere midlatitudes with the GEOS-CHEM model, J. Geophys. Res., 108(D15), 4449, doi:10.1029/2002JD002742, 2003.

Gardner, M. W. and Dorling, S. R.: Meteorologically adjusted trends in UK daily maximum surface ozone concentrations, Atmos. Environ., 34, 171-176, 2000.

Ghim, Y. S. and Chang, Y.-S.: Characteristics of ground-level ozone distributions in Korea for the period of 1990-1995, J. Geophys. Res., 105(D7), 8877-8890, 2000.

Jonson, J. E., Simpson, D., Fagerli, H., and Solberg, S.: Can we explain the trends in European ozone levels?, Atmos. Chem. Phys., 6, 51-66, 2006, http://www.atmos-chem-phys.net/6/51/2006/.

Lam, K. S., Wang, T. J., Chan, L. Y., Wang, T., and Harris, J.: Flow patterns influencing the seasonal behavior of surface ozone and carbon monoxide at a coastal site near Hong Kong, Atmos. Environ., 35, 3121-3135, 2001.

Lefohn, A. S., Shadwick, D. S., and Ziman, S. D.: The difficult challenge of attaining EPA's new ozone standard, Environ. Sci. Technol., 32, 276A-282A, 1998.

Lelieveld, J. and Dentener, F. J.: What controls tropospheric ozone? J. Geophys. Res., 105(D3), 3531-3551, 2000.

Li, J., Wang, Z., Akimoto, H., Gao, C., Pochanart, P., and Wang, X.: Modeling study of ozone seasonal cycle in lower troposphere over east Asia, J. Geophys. Res., 112, D22S25, doi:10.1029/2006JD008209, 2007.

Lin, C.-Y. C., Jacob, D. J., Munger, J. W., and Fiore, A. M.: Increasing background ozone in surface air over the United States, Geophys. Res. Lett., 27(21), 3465-3468, 2000.

Logan, J. A., Megretskaia, I. A., Miller, A. J., Tiao, G. C., Choi, D., Zhang, L., Stolarski, R. S., Labow, G. J., Hollandsworth, S. M., Bodeker, G. E., Claude, H., De Muer, D., Kerr, J. B., Tarasick, D. W., Oltmans, S. J., Johnson, B., Schmidlin, F., Staehelin, J., Viatte, P., and Uchino, O.: Trends in the vertical distribution of ozone: A comparison of two analyses of ozonesonde data, J. Geophys. Res., 104, 26 373-26399, 1999.

Low, P. S. and Kelly, P. M.: Variations in surface ozone trends over Europe, Geophys. Res. Lett., 19(11), 1117-1120, 1992.

Lu, H.-C. and Chang, T.-S.: Meteorologically adjusted trends of daily maximum ozone concentrations in Taipei, Taiwan, Atmos. Environ., 39, 6491-6501, 2005.

Luo, C., Ding, G., Li, X., Tang, J., and Zhou, X.: Preliminary analysis and comparison of results in field experiment of Sino-US atmospheric chemical cooperation investigation: PEM-WEST B, Acta Meteorol. Sinica, 56(4), 467-475, 1998. 
Luo, C., St. John, J. C., Zhou, X. J., Lam, K. S., Wang, T., and Chameides, W. L.: A nonurban ozone air pollution episode over eastern China: Observations and model simulations, J. Geophys. Res., 105, 1889-1908, 2000.

Mauzerall, D. L., Sultan, B., Kima, N., and Bradford, D. F.: $\mathrm{NO}_{\mathrm{x}}$ emissions from large point sources: variability in ozone production, resulting health damages and economic costs, Atmos. Environ., 39, 2851-2866, 2005.

Menezes, K. A. and Shively, T. S.: Estimating the Long-term Trend in the Extreme Values of Tropospheric Ozone Using a Multivariate Approach, Environ. Sci. Technol., 35, 2554-2561, 2001.

Naja, M. and Akimoto, H.: Contribution of regional pollution and long-range transport to the Asia-Pacific region: Analysis of longterm ozonesonde data over Japan, J. Geophys. Res., 109, 1306, doi:10.1029/2004JD004687, 2004.

Newchurch, M. J., Yang, E.-S., Cunnold, D. M., Reinsel, G. C., Zawodny, J. M., and Russell III, J. M.: Evidence for slowdown in stratospheric ozone loss: First stage of ozone recovery, J. Geophys. Res., 108(D16), 4507, doi:10.1029/2003JD003471, 2003.

Oltmans, S. J., Lefohn, A. S., Sheel, H. E., Harris, J. M., Levy, H., Galbally, I. E., Brunke, E.-G., Meyer, C. P., Lathrop, J. A., Johnson, B. J., Shadwick, D. S., Cuevas, E., Schmidlin, F. J., Tarasick, D. W., Claude, H., Kerr, J. B., Uchino, O., and Mohnen, V.: Trends of ozone in the troposphere, Geophys. Res. Lett., 25, 139-142, 1998.

Oltmans, S. J., Lefohn, A. S., Harris, J. M., Galbally, I., Scheel, H. E., Bodeker, G., Brunke, E., Claude, H., Tarasick, D., Johnson, B. J., Simmonds, P., Shadwick, D., Anlauf, K., Hayden, K., Schmidlin, F., Fujimoto, T., Akagi, K., Meyer, C., Nichol, S., Davies, J., Redondas, A., and Cuevas, E.: Long-term changes in tropospheric ozone, Atmos. Environ., 40, 3156-3173, 2006.

Ordóñez, C., Mathis, H., Furger, M., Henne, S., Hüglin, C., Staehelin, J., and Prévôt, A. S. H.: Changes of daily surface ozone maxima in Switzerland in all seasons from 1992 to 2002 and discussion of summer 2003, Atmos. Chem. Phys., 5, 1187-1203, 2005, http://www.atmos-chem-phys.net/5/1187/2005/.

Pochanart, P., Akimoto, H., Kinjo, Y., and Tanimoto, H.: Surface ozone at four remote island sites and the preliminary assessment of the exceedances of its critical level in Japan, Atmos. Environ., 36, 4235-4250, 2002.

Qin, Y., Tonnesen, G. S., and Wang, Z.: One-hour and eight-hour average ozone in the California South Coast air quality management district: trends in peak values and sensitivity to precursors, Atmos. Environ., 38, 2197-2207, 2004.

Richter, A., Burrows, J. P., Nuß, H., Granier, C., and Niemeier, U.: Increase in tropospheric nitrogen dioxide over China observed from space, Nature, 437, 129-132, doi:10.1038/nature04092, 2005.

Saitanis, C. J.: Background ozone monitoring and phytodetection in the greater rural area of Corinth - Greece, Chemosphere, 51, 913-923, 2003.

Simmonds, P. G., Derwent, R. G., Manningc, A. L., and Spain, G.: Significant growth in surface ozone at Mace Head, Ireland, 1987-2003, Atmos. Environ., 38, 4769-4778, 2004.

Solberg, S., Simpson, D., Jonson, J., Hjellberekke, A., and Derwent, R.: Ozone, in: EMEP assessment PART I: European perspective, edited by: Løvblad, G., Tarrasón, L., Tørseth, K., and Dutchak, S., Tech. rep., The Norwegian Meteorological Institute, Oslo, Norway, 2004.
Staehelin, J., Harris, N. R. P., Appenzeller, C., and Eberhard, J.: OZONE TRENDS: A REVIEW, Rev. Geophys., 39(2), 231-290, 2001.

Streets, D. G., Bond, T. C., Carmichael, G. R., Fernandes, S. D., Fu, Q., He, D., Klimont, Z., Nelson, S. M., Tsai, N. Y., Wang, M. Q., Woo, J.-H., and Yarber, K. F.: An inventory of gaseous and primary aerosol emissions in Asia in the year 2000, J. Geophys. Res., 108(D21), 8809, doi:10.1029/2002JD003093, 2003.

Tarasick, D. W., Wardle, D. I., Kerr, J. B., Bellefleur, J. J., and Davies, J.: Tropospheric ozone trends over Canada: 1980-1993, Geophys. Res. Lett., 22, 409-412, 1995.

Tarasova, O. A., Elansky, N. F., Kuznetsov, G. I., Kuznetsova, I. N., and Senik, I. A.: Impact of Air Transport on Seasonal Variations and Trends of Surface Ozone at Kislovodsk High Mountain Station, J. Atmos. Chem., 45, 245-259, 2003.

TOR-2: Tropospheric Ozone Research, EUROTRAC-2 Subproject Final Report, ISS GSF-National Research Center for Environment and Health, Munich, Germany, 2003.

Vingarzan, R.: A review of surface ozone background levels and trends, Atmos. Environ., 38, 3431-3442, 2004.

Vingarzan, R. and Taylor, B.: Trend analysis of ground level ozone in the greater Vancouver/Fraser Valley area of British Columbia, Atmos. Environ., 37, 2159-2171, 2003.

Wang, H., Tang, X., Wang, M., Yan, P., Wang, T., Shao, K., Zeng, L., Du, H., and Chen, L.: Characteristics of observed trace gaseous pollutants in the Yangtze Delta, Science in China (D), 46(4), 297-404, 2003.

Wang, M., Cheng, H., Ding, G., Tang, J., Yu, X., Liu, G., and Zhou, H.: Study on the composition of NMHCs and the variation of concentration at Linan and Shangdianzi atmospheric background station, Acta Meteorol. Sinica, 64(5), 658-665, 2006.

Wang, T., Cheung, V. T. F., Anson, M., and Li, Y. S.: Ozone and related gaseous pollutants in the boundary layer of eastern China: Overview of the recent measurements at a rural site, Geophys. Res. Lett., 28(12), 2373-2376, 2001.

Wang, T., Cheung, T. F., Li, Y. S., Yu, X. M., and Blake, D. R.: Emission characteristics of $\mathrm{CO}, \mathrm{NO}_{x}, \mathrm{SO}_{2}$ and indications of biomass burning observed at a rural site in eastern China, J. Geophys. Res., 107(D12), 4157, doi:10.1029/2001JD000724, 2002.

Wang, T., Wong, C. H., Cheung, T. F., Blake, D. R., Arimoto, R., Baumann, K., Tang, J., Ding, G. A., Yu, X. M., Li, Y. S., Streets, D. D., and Simpson, I. J.: Relationships of trace gases and aerosols and the emission characteristics at Lin'an, a rural site in eastern China during spring 2001, J. Geophys. Res., 109, D19S05, doi:10:1029/2003JD004119, 2004.

Wang, Z., Li, J., Wang, X., Pochanart, P., and Akimoto, H.: Modeling of Regional High Ozone Episode Observed at Two Mountain Sites (Mt. Tai and Huang) in East China, J. Atmos. Chem., 55(3), 253-272, doi:10.1007/s10874-006-9038-6, 2006.

WMO: Scientific Assessment of Ozone Depletion: 2002, Global Ozone Research and Monitoring Project-Report No. 47, Geneva, 2003.

Xu, X., Xiang, R., Ding, G., and Li, X.: Continental background NMHC concentration, composition, and relation to surface ozone, in: Atmospheric Ozone Variations and Its Effect on the Climate and Environment in China, edited by: Zhou, X., pp. 67-81, Meteorological Press, Beijing, 1996.

Xu, D., Yap, D., and Taylor, P. A.: Meteorologically adjusted ground level ozone trends in Ontario, Atmos. Environ., 30(7), 
1117-1124, 1996.

Yamaji, K., Ohara, T., Uno, I., Tanimoto, H., Kurokawa, J., and Akimoto, H.: Analysis of the seasonal variation of ozone in the boundary layer in East Asia using the Community Multiscale Air Quality model: What controls surface ozone levels over Japan?, Atmos. Environ., 40, 1856-1868, 2006.

Yan, P., Li, X., Luo, C., Xu, X., Xiang, Y., Ding, G., Tang, J. , Wang, M., and $\mathrm{Yu}, \mathrm{X}$.: Observational analysis of surface $\mathrm{O}_{3}, \mathrm{NO}_{\mathrm{X}}$ and $\mathrm{SO}_{2}$ in China, Quart. J. Appl. Meteor., 8(1), 53-60, 1997.

Zhang, J., Wang, T., Chameides, W. L., Cardelino, C., Kwok, J., Blake, D. R., Ding, A., and So, K. L.: Ozone production and hydrocarbon reactivity in Hong Kong, Southern China, Atmos. Chem. Phys., 7, 557-573, 2007,

http://www.atmos-chem-phys.net/7/557/2007/.
Zhang, X., Zhang, P., Zhang, Y., Li, X., and Qiu, H.: The trend, seasonal cycle, and sources of tropospheric $\mathrm{NO}_{2}$ over China during 1996 2006 based on satellite measurement, Science in China Series D, 50(12), 1877-1884, 2007.

Zhou, X., Luo, C., Ding, G., Tang, J., and Liu, Q.: Preliminary study of background variations of atmospheric ozone and its precursors over eastern China, Science in China (B), 24(12), 13231330, 1994. 